\title{
TTR
}

Traduction, terminologie, re?daction

\section{Gay Community, Gay Identity and the Translated Text}

\section{Keith Harvey}

Volume 13, numéro 1, 1er semestre 2000

Idéologie et traduction

Ideology and Translation

URI : https://id.erudit.org/iderudit/037397ar

DOI : https://doi.org/10.7202/037397ar

Aller au sommaire du numéro

\section{Éditeur(s)}

Association canadienne de traductologie

ISSN

0835-8443 (imprimé)

1708-2188 (numérique)

Découvrir la revue

Citer cet article

Harvey, K. (2000). Gay Community, Gay Identity and the Translated Text. TTR, 13(1), 137-165. https://doi.org/10.7202/037397ar

\section{Résumé de l'article}

Communauté gay et identité gay à l'intérieur de la traduction — Dans cet article, l'auteur explore les multiples notions de " communauté » et " d'identité " gays et les problèmes de traduction qui en découlent. Il examine d'abord les ramifications théoriques, politiques et personnelles que peuvent avoir ces deux notions pour le sujet gay. Il soutient que ces deux notions se redéfinissent mutuellement de façon constante, et plus précisément, qu'elles semblent se chevaucher lorsque leurs dimensions concrètes/imaginées et internes/externes entrent respectivement en jeu. L'auteur affirme que les oeuvres traduites jouent un rôle crucial dans la recherche de la subjectivité distincte des gays. Par la suite, il donne un extrait d'un texte espagnol-anglais traitant de l'émergence de l'identité gay qui est mise en valeur en traduction. Enfin, un texte anglais accompagné de sa traduction française permet de voir comment des conceptions culturelles distinctes de l'identité sexuelle se manifestent à travers l'écrit.
Tous droits réservés (C) TTR: traduction, terminologie, rédaction — Les auteurs, 2000
Cedocument est protégé par la loi sur le droit d'auteur. L'utilisation des services d'Érudit (y compris la reproduction) est assujettie à sa politique d'utilisation que vous pouvez consulter en ligne.

https://apropos.erudit.org/fr/usagers/politique-dutilisation/ 


\section{Gay Community, Gay Identity and the Translated Text}

\section{Keith Harvey}

[...] until we organise ourselves block by neighbourhood by city by state into a united visible community that fights back, we're doomed. (Larry Kramer (1985) The Normal Heart: Act Two, Scene Thirteen, London, Methuen, p. 77)

[...] le traducteur est cet individu qui représente, dans sa pulsion de traduire, toute une communauté dans son rapport avec une autre communauté et ses œuvres.

(Antoine Berman (1984) L'Épreuve de l'étranger: culture et traduction dans l'Allemagne romantique, Paris, Gallimard, p. 283)

In this article', I wish to argue that the translation of texts whose subject matter is homosexual experience and struggle raises complex issues with regard to the notions of "gay community" and "gay identity". At the same time, I will suggest that recourse to the notions of "community" and "identity" illuminates and clarifies the issues arising from the translation of so-called "gay texts" at several levels, from the elaboration of a gay reading position to the nature of the possibilities and constraints facing the translator. In particular, I will demonstrate how the translated text can be seen to register the influence of factors peculiar to a receiving culture. Through this

\footnotetext{
'An oral version of this article was first given at the Third ITI International Colloquium on Literary Translation, held at the University of Sheffield, UK, 1 - 3 September 1998.
} 
discussion, it is hoped not only that translation studies themselves will gain from an increased awareness of identity/community debates, but also that those disciplines which regularly make use of such debates (gender studies, women's studies, queer studies, etc.) will find that translation constitutes a useful perspective from which to revisit them.

\section{Writing, community and identity}

Like many other minoritised cultural groups, homosexuals in late twentieth-century Britain and the United States have found it personally and politically useful to foster a communal identity in order to resist oppression and to forge a sense of history and a distinct set of socio-cultural values. To contribute to this project, authors whose sexual desires and behaviour are directed principally towards members of their own gender have increasingly explored the personal and political consequences of their desires in their writing, often thereby blurring the generic divisions between autobiography and fiction ${ }^{2}$. As a result, the categories of "gay writing" and "gay fiction" have assumed increasing validity in recent Anglo-American letters for writers, readers and critics alike ${ }^{3}$. However, it is important to note that writing in this generic category not only emerges from gay community-building, it also actively contributes towards its elaboration. Thus, gay readers will turn to gay fiction in order to see reflected and illuminated aspects of their own experience and also to have reconfirmed the existence of other voices who speak of struggles and joys comparable to their own.

\footnotetext{
${ }^{2}$ Notable examples of this trend in English are provided by Edmund White's $A$ Boy's Own Story (1982), The Beautiful Room is Empty (1988), The Farewell Symphony (1997). See also the article by E. White "Today the Artist is a Saint who Writes his Own Life - Edmund White on the Genre of Gay Autofiction" in London Review of Books, Vol. 17, Issue 5, 9 March 1995, pp. 6-8.

${ }^{3}$ See, for example, the discussions in R.W. Hall, "Gay Fiction Comes Home" in New York Times Book Review, June 19th 1988; E. White, "Out of the Closet, on to the Bookshelf' in The Burning Library: Writings on Art, Politics and Sexuality, London, Chatto and Windus, 1994, pp. 275-283; D. Leavitt, "Introduction" in M. Mitchell (ed.) The Penguin Book of International Gay Writing, Harmondsworth, Penguin, 1995, pp. xiii-xx.
} 
The translation of texts on homosexual themes raises interesting questions with regard to the project of community for gay people. For example, how far has community building depended on the appearance in a receiving culture of foreign texts in translation? Interesting in this regard is Venuti's (1998) account ${ }^{4}$ of the way in which Pierre Louÿs's pseudotranslation from a putative Ancient Greek text, Les Chansons de Bilitis (1895), contributed to the articulation in early twentieth-century French letters of lesbian sexual experience and to the "construction of the lesbian author" (Venuti, 1998, p. 45). Then again, if writing about homosexual experience is not established generically in a given culture, is gay writing from another culture likely to suffer repression or more subtle forms of censorship and transformation in translation? Relevant here is Toury's (1995) account ${ }^{5}$ of the $20^{\text {th }}$ century history of the Shakespearean sonnet cycle in Hebrew translation. Toury shows how early versions of the sonnets addressed to a young man were translated with the addressee's gender switched to female. He imputes this transformation to "the demands of the rigid cultural model laid down by the receptor culture" (p. 118), i.e. that of the "observant Jew" in the early decades of the century. Such textual practice is, of course, unlikely to contribute to the formation of a selfidentified homosexual reading community in the target community.

It is important at the outset to note that the issue of community - and its articulation/elaboration through source and target texts - cannot be fully thought through without addressing the complex question of identity. As I will seek to illuminate in this article, the terms "identity" and "community" are not by chance twin sites of contention and description for gay people, including activists and researchers in contemporary lesbian and gay studies. Rather, they are terms which can best be understood in relation to each other. Attempts to define one without the other are beset with difficulties, largely because they are, I suggest, systemically mutually supporting for political and cultural reasons. Thus, the claiming of an identity position presupposes the existence of (groups of) others with whom one can

${ }^{4}$ In L. Venuti, The Scandals of Translation: Towards an Ethics of Difference, London and New York, Routledge, 1998, pp. 34-46.

${ }^{5}$ In G. Toury, Descriptive Translation Studies and Beyond, Amsterdam, John Benjamins, 1995, pp. 114-128. 
"identify" or from whom one is able to dissociate. Similarly, the projection of a community base requires the prior assumption that specific types of identity can be - however temporarily and fragilely - imagined and worked with. In other words, the question of what "is" a gay identity or a gay community is subordinated to the question of how the two notions relate and support each other. "What is $x$ ?" soon becomes displaced by "For what purpose(s) are we advancing the notion $x$ ?". Just as was suggested above with regard to "community", "identity" can usefully be seen both as a textual product as well as a category that feeds into the elaboration of texts. That is, conceptions and possibilities of identity formation emerge from textual encodings and can also be the spur to such encodings, motivating writers, readers and translators. Understood in this way, "gay writing" is, perhaps above all else, a literary genre that explores the parameters of gay experience in order to validate an identity position and create an interactional space for the formulation and reception of gay voices. Translation as an activity - and translated texts as products - operate with the textual elaboration of this identity position, either to introduce it as an innovative device in the target cultural polysystem ${ }^{6}$ or to modify (heighten or attenuate) it for the target reader as a consequence of the target cultural pressures to which he or she is subject.

\section{Problematising gay identity and community}

It is one of the chief ironies of modern gay life in Britain and America that, just as the terms "gay identity" and "gay community" have become increasingly accepted and actively employed by many nonacademic gay people, attacks upon and subversions of these terms have multiplied within lesbian and gay studies, within both its theoretical and politically-oriented tendencies. Thus; while the flourishing English-language gay press regularly reinforces its readers' sense of a sexual identity and of a communal belonging with assumptions about what it is to "be gay" and to belong to a community of people who

\footnotetext{
6 "Polysystem" is a term I derive ultimately from I. Even-Zohar, "Polysystem Theory" in Poetics Today, Vol. 1, Nos 1-2, 1979, pp. 287-310. By using it here, I am not necessarily invoking or subscribing to the possibility of a fully worked-out semiotics of culture. However, its use allows one constantly to keep in mind the multilayered complexity of the contexts in which cultural forms are produced and received.
} 
identify with this sexual category ${ }^{7}$, gay thinkers have spent much critical time on the problems of a) defining the notion of "gay" and b) the political implications of its definition (or lack of definition) ${ }^{8}$. Among the questions raised by the definitional problem of "gay" are: Who is included and excluded from the definition? Is there a set of behavioural and/or psychological criteria which can be considered a prerequisite for its attribution? How fluid could and should the definition $b^{9}$ ? Is the definition of universal validity or is it culturally(and historically-) specific ${ }^{10}$ ? How does "gay" relate to the apparently (and self-consciously) more problematic category "queer"? Among the political implications of the definition is the extent to which it helps or hinders the avowed or implicit social and cultural objectives of selfidentified gay people. Is the model of our political aspirations congruent with the liberal-pluralist position advocating equality within diversity? Or is the challenge of "gay" more radical, aspiring to destabilise the prevailing cultural conceptions of gender roles as well as the social codes regarding sexual morality (e.g. the division between public and private spaces)? And, again, does the advancement of a definition contribute to an emerging transcultural emancipatory strategy or, rather, does it constitute an Anglo-American neoimperialist ruse? It is important to note already that the political implications of "gay" do not simply develop, logically and

${ }^{7}$ For example, the popular British weekly newspaper Boyz announces on its front page that its contents are "For gay adults only".

"One recent commentator (Sinfield 1998) is already envisaging a "post-gay" world, preferring to use (revert to?) the term "subculture" rather than "community" "because it doesn't connote cosiness" (A. Sinfield, Gay and After, London, Serpent's Tail, 1998, p. 199).

9 See, for example, J. M. Donovan, "Homosexual, Gay, and Lesbian: Defining the Words and Sampling the Populations", in Gay and Lesbian Studies, ed. H. L. Minton, New York, Harrington Park Press, 1992, pp. 27-47.

${ }^{10}$ Relevant here is S. Murray, "Stigma Transformation and Relexification in the International Diffusion of Gay", in Beyond the Lavender Lexicon: Authenticity, Imagination, and Appropriation in Lesbian and Gay Languages, ed. W. Leap, Luxembourg, Gordon and Breach, 1995, pp. 297-315. This illuminating article explores the transformed meanings of the lexical item "gay" in different national-cultural contexts. 
chronologically, out of the prior establishing of a working definition. Indeed, in many cases the definition is itself posited in order to support a particular cultural and political stance. Thus, one might decide that for political reasons one's conception of gayness will exclude people whose having regular sex with members of their own gender does not entail a rejection or challenge of an otherwise tranquil heterosexual existence (marriage, family etc.). This definitional exclusionary move will have been carried out, then, in order to facilitate the advancement of a particular political project.

It is worth remarking that suspicion of the effects and usefulness of conceptions of identity and community range across the political continuum. Those gay thinkers and activists on the political right ${ }^{11}$ object that a postulated "gay identity" risks the overprioritisation of sexuality in the construction (and projection) of self to the detriment of other - perhaps more important - aspects of identity. They are unhappy with the isolation from mainstream social practices and institutions that a mobilisation around a gay identity category might entail. What is more, they point out that gay identity politics seems linked - causally or coincidentally — with a commercial visibility and commodification of "gay" which can lead to limitations on individual freedoms. Bruce Bawer is one of the most vocal of those who regard identity and community formations around "gay" with distrust:

In the eyes of the queer establishment, gay people share not only a sexual orientation but a culture, a community, a common identity; they belong to a tribe. For a gay person [...] to question the received values of what is known as the "gay community" [...] is to invite attacks from the gay-left establishment. (Bawer, 1996, p. 139)

In fact, the "queer establishment" that Bawer has in his sights has spent most of its time since the mid-1980s challenging traditional identity categories - whether they be of gender or sexuality - and the politics founded upon them. Thus, Butler (1990), Sedgwick (1991), Halperin

"For example, B. Bawer, A Place at the Table: The Gay Individual in American Society, New York and London, Poseidon Press, 1993. See also A. Sullivan's cogently argued, "The Politics of Homosexuality", in Beyond Queer: Challenging Queer Left Orthodoxy, ed. B. Bawer, New York, The Free Press, 1996, pp. 60-85. 
(1995) have all increasingly worked with a performative conception of identity which theorises any such category as a discursive effect of language, gesture and visual semiosis. Models of identity predicated upon a notion of "depth" are regarded as fictions - indeed, as products of discourses which conceal their own arbitrary and conventional processes with consummate skill. However, as Butler points out, a performative conception of identity allows - through the central reinforcing mechanism of repetition - for the subversion and multiplication of its own effects of identity. Thus, through the possibilities opened up by the requirement of repetition, nonforeclosed, provisional "identities" can still, according to Butler, constitute rallying cries for political action ${ }^{12}$. Given such a view, it is not surprising that parody occupies a key place for Butler in the political implications of a performative theory. Parody allows her to envisage a sexual/gender politics whose goal is to reveal the extent to which, as far as identity categories are concerned, "the original [is] nothing other than a parody of the idea of the natural and the original" (Butler, 1990, p. 31).

The theoretical sophistication of much American queer thinking derives largely from French postmodern and deconstructionist thought. Writers like Sedgwick and Halperin employ concepts and methods from these schools in order to counter both the slide to conservatism and complacency within the women's and gay movements as well as the endlessly protean nature of sexism and homophobia. The central thrust of their work manifests a strong penchant for teasing out semantic slippage and a distrust of cultural and political consensus. It is heavily textual and semiotic in its methods and radical - even utopian - in its socio-sexual vision. However, as gay film theorist and academic Andy Medhurst (1991) has warned, the postmodern fluidity favoured by "queer" conceals a bitter irony for minority identities and the groups they strive to form. Thus, at the very moment that gay people are able to articulate for the first time a semblance of individual and communal experience, they are being invited to renounce outmoded concepts like "identity". The political consequences of such

${ }^{12}$ For more discussion of these issues, see D. C. Stanton's "Introduction: The Subject of Sexuality", in Discourses of Sexuality from Aristotle to AIDS, ed. D. C. Stanton, Ann Arbor, University of Michigan, 1993, pp. 1-15. 
a renouncement could be grave indeed. As Medhurst points out, "[...] it is much harder to claim civil rights for a discursive construction" (Medhurst, 1991, p. 206) ${ }^{13}$. To bring home his point (and in a characteristic gay autobiographical move) he continues:

I have read my Foucault, I am aware of the conceptual shortcomings of a timeless, essentialist homosexual identity, I might even want to take the step of putting quotations [sic] marks around the word "gay" - but the man who queerbashed me some years ago did not put quotation marks around his fists. (p. 208)

It would appear that many non-academic gay men in Britain today concur with Medhurst, considering the label "gay" - both as it relates to "identity" and "community" - as an important, valid and workable outcome of years of struggle for visibility and equality. Let us take just one example. Zorro, a gay-funded project on HIV/AIDS needs assessment in Brighton, UK, interviewed over 13,000 gay-identified men throughout 1997. In one of the questions, the interviewees were specifically asked whether they believed that they belonged to the town's "gay community". Peter Scott, one of the authors of the report to emerge from the study, notes: "A thousand men in Brighton (four fifths of our samples) say they are part of a gay community" (Scott, 1991 , p. 1). This result does not necessarily indicate a lack of theoretical sophistication on the part of the men surveyed. Rather, it points, I suggest, to a key factor in any discussion of identity/community, one which short-circuits and invalidates attempts to pin down what it might "be": namely, that "identity"/"community" are real and valid as concepts as long as those that choose to work and think with them project them as such ${ }^{14}$.

\footnotetext{
${ }^{13}$ It is for comparable cultural political reasons that G. Spivak has argued for the self-conscious and "strategic use of a positivist essentialism", in In Other Worlds: Essays in Cultural Politics, New York, Methuen, 1987, p. 205.
}

${ }^{14}$ Note, in this connection, how a constructionist turn on the question of identity does not necessarily exclude an acknowledgement of subjective judgments and their potency. Alan Sinfield has commented: "Sexual identity depends not on a deep-set self-hood (though it may feel otherwise), but on one's particular situation within the framework of understanding that makes certain, diverse, possibilities available; which makes some ideas plausible and others not". (A. Sinfield, The Wilde Century: Effeminacy, Oscar Wilde and the 
Identity and community: dimensions, relations, translations

At this point we might turn our attention from the controversies over the meanings and implications of "identity" and "community" to the issue of the relationship between the two concepts. If defining them separately proves an elusive and ultimately futile project, how, we might ask, do they together support and sustain each other? Key questions in such an enquiry become: Is a notion of "identity" necessary before we can think the possibility of "community"? To what extent do communities produce the identities that constitute them? Carol Warren's work, although from the early days of affirmative and non-pathologising research into homosexual behaviour and culture, remains useful here. In Identity and Community in the Gay World (1974), Warren regarded "community" as a notion that contains two dimensions. Firstly, it is a concrete matter of temporal and geographical space, of verbal and social interaction, and of a proliferating network of relationships. In other words, "community" is realised in real time and physical locations by people choosing to gather together and share experience. As she put it, "people, in relationships, live out the idea of community" (p. 13). This understanding of community does not require one to begin with a definition in order to establish whether one belongs to it or not. Rather, it suggests that communities can be said to occur de facto when people materially and interactionally relate. Secondly, Warren suggested that "community" enjoys the status of an idea. That is, "community" implies a bond of fellowship that is shared outside actual settings ${ }^{15}$. This imagined dimension was posited by Warren to indicate a necessary and positive element to the understanding of "community" and its functioning for gay people. For her, the imagined component stood alongside and contributed to the concrete one. Community-as-

Queer Moment, London, Cassell, 1994, p. 11). The clause "though it may feel otherwise" is no less significant here for being placed in parentheses.

15 This more abstract dimension looks forward to B. Anderson's Imagined Communities: Reflections on the Origins and Spread of Nationalism, London, Verso, 1983. Anderson notes that few, today, meet face to face the other members of the communities to which they (are said to) belong. Communities, Anderson concludes, cannot be distinguished by their degree of truth or falsehood but, instead, by the style in which they are imagined. 
idea allows gay men to carry with them the memory of and aspiration to concrete interaction with other gay men; it also allows those gay men who - for geographical, socio-cultural, or even domestic reasons - have no access to the spaces of gay contact to sustain a sense of belonging, sometimes in the face of appalling isolation and violence.

When turning to the other term in the pairing, Warren approaches it through her understanding of community. Thus, the central question of identity formation - "Who am I?" - is recast as "Where do I belong?". Warren is unambiguous about the sustaining power of community for the individual in a marginalised group: "Identity is forged within community" (p. viii; see also pp. 162-163). Here, one needs only consider how the use of the term "gay man" in itself constitutes a cultural identity in a way that is quite different from the implications of "homosexual". The latter may imply certain behavioural preferences that make it synonymous with "gay", it is nonetheless devoid of the cultural resonances of "gay". The cultural force of "gay" stems directly from its subscription to and origin in a set of community values. In short, "I am gay" as a statement of identity means, quite literally, "I belong to the gay community".

Building on Warren's work, I would like to suggest that two dimensions of identity formation can usefully be distinguished. The internal dimension grows out of a consciousness of self and a process of reflection and reflexivity. Thus, questions such as "Am I different?" and "Where do I belong?" emerge from the individual's interrogations of her or his components of selfhood and the priorities that he or she chooses to accord them. The external dimension of identity formation is concerned with aspects of self-presentation, which include behaviour, gesture, language - in short, the semiotics of identification. As many have noted ${ }^{16}$, the semiotic realm is particularly important for gay culture as the hidden nature of sexual desire requires that subjects develop fluency in and attentiveness to coded behaviour. I would suggest that in most cases a preoccupation with the external dimension

16 See, for example, A. Sullivan, Virtually Normal: An Argument About Homosexuality, London, Picador, 1995, pp. 71-72; 1. Lucas, Impertinent Decorum: Gay Theatrical Manoeuvres, London, Cassell, 1995, pp. 83-110. 
of identity formation would succeed upon the processes of the internal dimension. The latter, however, is an ongoing feature of the gay self, which requires constant re-interrogation and shoring up in the face of the pressures placed upon it by the dominant culture. The ordinary state of gay selfhood, then, is characterised by a perpetual movement between the internal and external dimensions of identity formation. What this simple twofold understanding of identity allows is a perception of linkages with the posited concrete and imagined components of community. Thus, the external aspects of identification processes link directly with the concrete aspects of community space and interaction; self-presentation, behaviour, language - these are all necessarily lived out in concrete community settings. As noted before, these settings are not just physical (bars, parties, gyms, cruising grounds, etc.), but also interactional. For example, the verbal style known as camp is an interactional space that gay men, in particular, have developed for both defensive purposes and for reasons of bonding and solidarity with other queers ${ }^{17}$.

As for the internal processes of identity formation, there would appear to be a clear link between these and the imagined component of community. Thus, a crucial element in such processes is the imagination/projection of groups of others with whom one can associate and feel at home. Viewed in this manner, the presence of texts that project in their subject matter and by their very existence the possibilities of such groups of others is crucial to both internal identity formation and imagined community projection. Such texts may well be the result of translation, of the introduction into a target cultural polysystem of representations of selfhood and community organisation that have not been articulated or, alternatively, that have been proscribed in the receiving culture. In short, the space of literature including, crucially, translated literature - is one in which a (gay) community can be imagined by the reader. Clearly, foundational work in translation history is waiting to be accomplished in this area. A key research question is likely to be: How generalisable across cultures and

17 With regard to translation, the representation of camp in fictional texts presents the translator with complex issues relating not only to verbal figures, but also more crucially to the visibility and function of gay identities in fictional worlds. See K. Harvey, "Translating Camp Talk: Gay Identities and Cultural Transfer", in The Translator 4: 2, 1998, pp. 295-320. 
periods is the notion of "gay writing"? Such a question reveals how relevant the disciplinary link between translation studies and comparative literature remain $\mathbf{s}^{18}$. Its broad cultural and historical sweep also points up immediately the extent to which the notion of "contexts" in translation studies requires serious theoretical endeavour. From a perspective in which "gay writing" does enjoy critical validity, supplementary research questions include: Does gay writing suffer from a particular "translation deficit" in a given culture? If so, why? Alternatively: When was a gay author's work first translated? What were the material conditions of its translation (including issues of the translator's own sexual identity position, the nature of the publishing company and list the work first appeared in, etc.)? How was it translated? How does the explicitly gay material emerge from the translation process? ${ }^{19}$

In the absence of such work, I am reminded of my own experience as a gay adolescent in 1970 s Britain, turning to translations of homosexual French writers (Genet, Gide, Proust) in paperback in order to counter my own isolation and to bolster an incipient and fragile identity position as a gay man. At seventeen, I read Genet for the first time in translation. A paperback series of Genet's fiction that particularly caught my eye as a result of its "packaging" was published in London by Panther books. The covers of these translations featured the photograph of the torso of a smooth, muscular young man, halfturning his back on the viewer and further obscured from view by a staged lifting over the head of a T-shirt. The photographs at one and the same time revealed and hid their subject, enticing the gay viewer into a complex process of desire and thwarted identification. Drawing on a long tradition of Anglo-American homosexual iconography (bodybuilding magazines, even fashion catalogues), the photos promised something about the text they "covered" which was fundamentally different from the world of low-life murderers, thieves,

\footnotetext{
${ }^{18}$ See S. Bassnett Translation Studies, London, Routledge, $19912^{\text {nd }}$ ed. on this relation.

${ }^{19}$ From the angle of lesbian and gay studies, research is also needed into the importance specifically translated texts have had in the emergence in late twentieth century Anglo-Saxon culture of gay identities, communities, political projects and cultural forms.
} 
pimps and prostitutes that is developed in Genet's fiction. These photos in fact signalled the possibility of a domestication of Genet's transgressive universe on Anglo-American terms. This possibility certainly facilitated my reading of the texts as manifestos of homosexual emancipation. At the time, I needed to make any text that spoke of homosexuality a document that contributed to my own tentative gay agenda. Genet's novels helped to break the silence which the English literary canon seemed to impose on homosexuality ${ }^{20}$.

After Genet, I scoured Gide and Proust - still in translation - for passages that would help me make sense of self and project an imagined community. I remember in particular the Penguin Modern Classics edition of Gide's Journals (1978) with their accounts of the author's visits to a bed-ridden Proust in order to debate the questions of "inversion". Without these paperbacks in translation, I do not know where I would have turned for homosexual voices; the "gay fiction" that was emerging at that time in the Unites States ${ }^{21}$ was not well enough known in Britain for me to become aware of it - and it certainly did not enjoy the canonical status of the aforementioned French authors. I see now, of course, that there is a deep irony in my co-opting of these authors to a tradition of gay writing. Genet's perpetual quest for states of abjection and repression as the desired condition for an intensified jouissance squarely disables the project of emancipation and equality that I was trying to articulate for myself. Further, as Corydon (1984) makes clear, Gide is chiefly preoccupied with an idealised classical model of pederasty; he is indifferent -

${ }^{20}$ When, at about the same time, I timidly told an English teacher at school that I had just read E.M. Forster's Maurice (first published posthumously in London, Edward Arnold, 1971), I was informed dismissively that the novel did not "really" belong to Forster's ouvre. Thus, a key text for my internal identity formation and imagined community projection was summarily devalued by a spokesperson for the dominant culture. In this connection, Adrienne Rich has described the way figures in authority "such as a teacher" can provoke a kind of "psychic disequilibrium" by describing the world in such a way that you are absent from it: "as if you looked into a mirror and saw nothing" (quoted in A. Sinfield, Cultural Politics - Queer Reading, London, Routledge and Philadelphia/University of Pennsylvania, 1994, pp. viii-ix).

${ }^{21}$ For example, A. Holleran, The Dancer from the Dance, New York, Morrow, 1978; L. Kramer, Faggots, New York, Random House, 1978. 
maybe even hostile - to adult same-sex relations ${ }^{22}$. And Proust, of course, is notoriously ambivalent about the "inverts" he portrays in $\dot{A}$ la recherche du temps perdu. Research would be required to establish whether the translations I read actually facilitated an Anglo-American gay reading. What I can suggest, however, is that this writing's cultural otherness was in fact part of its appeal. The very distance inscribed in these texts (through their historical and cultural settings) and in their textuality (I never forgot that they were translations of an original that was inaccessible to me) helped to maintain their attraction for me as a reader. Indeed, this distance was actually — paradoxically — the space in which I was able to work out the message I wanted to hear and could get nowhere else in English language texts. A complete domestication of the text by a translator was not necessary in this sense. Indeed, it might even have been counterproductive. The text's cultural and textual otherness was an image of the sexual otherness I was seeking to articulate to myself. Its foreigness, filtered through translation, showed me the possibility of other worlds. The translated text was queer in every sense of the word, and I could use its queerness in the formative process of imagining a community above language and cultural differences.

\section{Translated selves: the case of Goytisolo}

To illustrate the complexities involved in processes of identification and communal belonging, I wish to focus here on a short passage from a translated text, Juan Goytisolo's Realms of Strife (1986), translated by Peter Bush (1990). My principal reason for focusing on the translation of this text stems not from any marked transformations carried out on the source text by the translator. Rather, it is because the complex identification/dis-identification processes that the passage both takes as its subject matter and also enacts textually are thrown into still greater relief by the translated status of Bush's text. In a way not dissimilar to the queer distance I found in reading Genet and Gide in English, this text's translatedness opens up a space that enriches our reading of it.

${ }^{22}$ On this point, see C. Robinson, Scandal in the Ink: Male and Female Homosexuality in Twentieth-century French Literature, London, Cassell, 1995, pp.152-156. 
Realms of Strife is the second volume of Goytisolo's autobiography. Towards the end of the book, Goytisolo recounts his final coming to terms with the fact that he is homosexual. The most crucial external act of "coming out" is to Monique, Goytisolo's longterm female partner (and future wife). After dis-covering his homosexuality to her, he moves temporarily to Tangiers, a city that allows him the space and opportunity to live out his same-sex desires. The autobiography then quotes from letters sent to Monique at the time of the North African sojourn. The discourse context for these passages is thus already shot through with the disjunctures between identities past and present, between self and other. Goytisolo, the writer in selfimposed exile from Spain and - momentarily - from France, writes to his heterosexual lover against the backdrop of a recent disidentification with his heterosexual self. National and sexual identity are both poised precariously between categories in this passage, with Tangiers providing a fleeting paradisiacal realm in which exile is the condition for boundless sexual pleasure. Then there is also the textual disjuncture in this passage between the narrating self that organises the autobiographical material throughout most of the book and the " $\Gamma$ " present in the letters. This "I" is cited, observed, looked back upon. The Goytisolo of Realms of Strife reflects back upon the Goytisolo of the coming out period, who in turn contrasts himself with a previous heterosexual self. At one point during the Tangiers letters, Goytisolo writes to Monique:

One observation that will interest you: while European homosexuals usually reveal themselves by imitating women, here, in contrast, they take on an extra layer of exaggerated virility. That's what attracts me to them and helps me to distinguish them without fail, since naturally there are plenty who aren't. (Bush, 1990, p. 251)

A passage such as this is clearly interesting for what it reveals of the performative nature of gay subcultural identities. A strategy of parody of the gendered binarisms operative in the dominant culture emerges from these lines as the key to a general semiotics of camp. This strategy is not limited to the male parody of femininity. Goytisolo's remarks alert the ethnographer (and translator) to the fact that different surface manifestations of the same underlying parodic trait need distinguishing. 
However, more interesting still is the manner in which the systemic requirements of the target language serve to underscore Goytisolo's continued distance from other homosexuals. After specifying that he is making his remarks for Monique (they will "interest you") ${ }^{23}$, Goytisolo observes how they - homosexuals behave. In doing so, Bush's text multiplies the incidence of third person pronouns ("themselves... they... them... them"), thereby reinforcing in distinct target-language terms the emerging dichotomy between "me" and "them". For example, the target text clause "they take on an extra layer of exaggerated virility" contains a pronoun that is absent from the source text ("asumen al contrario un suplemento de virilidad exacerbada", p. 298: original italics, my underline) ${ }^{24}$. While the absence of horizontal fraternity between the "me" and the "them" is of course present in the source text in source language terms (i.e. through verb inflection), the target text underlines the presence of the dichotomy by the proliferation of a distinct class of lexical item, i.e. the personal pronoun. In other words, the surface of the passage demonstrates a particularly high density of pronominal forms that accentuates the "me-them" dichotomy for the target text reader. Also in the same passage, it is worth noting how the elliptical relative clause "there are plenty who aren' $t$ " - provides another twist to the complex toing-and-froing of (dis-)identification. Are we to understand: "There are plenty of homosexuals who aren't exaggeratedly virile"? Or rather: "There are plenty of virile men who aren't homosexual"? The source text's "abundan quienes no lo son" (original italics) also allows both readings. The target text then seems here to preserve an intriguing ambiguity present in the source.

To employ the analysis of identity and community developed above, one could suggest that while Goytisolo's internal process of identity formation as a homosexual may have started at the time of writing the letters to Monique, the imagined (and concrete) processes of community belonging had not yet emerged. This is perhaps why one feels uneasy attributing a label such as "gay writing" to this work.

${ }^{23}$ Monique's liking for homosexuals (including, notably, Genet) has been a feature of the book throughout.

${ }^{24}$ In Spanish, subject pronouns are not normally required as the inflected verb form makes the subject explicit. 
There are positions articulated in Goytisolo's text that block its use as a space for gay community building. I do not mean to suggest that the distance encoded between the homosexual writer and "the homosexuals" in a passage such as this is by any means unusual in the slow coming out process which gay people are obliged to undergo in most cultures (a process which is itself a kind of slow translation of one self into another). "Am I one of them?" even represents a necessary stage on the way to communal belonging. But, perhaps the complexities of multiple exile in Goytisolo's selfhood are too strong ever to allow the work to feed into a project of communal strengthening. Then again, perhaps the cultural and historical circumstances of a Spaniard - albeit homosexual - living in Paris in the middle decades of this century are destined to make the latetwentieth century Anglo-Saxon notion of "gay community" irreducibly foreign. Be that as it may, it is interesting to note how reading this text in English translation contributes importantly to an understanding of the dramas Goytisolo was playing out within himself. The translation is yet another text in a proliferating chain (letter, autobiography) of texts about self, difference and distance. Just as the autobiography reflects upon the epistle, so the translation reflects upon the original. The translation in its paradoxical oneness and difference with the original precisely enacts the identity trouble explored in Goytisolo's book. In this sense, readers of the translation have their understanding of the processes worked through in the text significantly enhanced. One might even say that, as a result, readers of the translation enjoy an important literary advantage over readers of the source text.

\section{Gay signs and translational pressures}

Finally, in this exploration of identity/community through the lense of translation/translatedness, I would like to give an example of how translation has to contend with textual encodings of gay communal signs and how these encodings undergo transformation in the process of translation. This transformation can enhance the presence of gay signs $^{25}$ or - as is the case in the following example - diminish their

${ }^{25}$ See, as an example, Keenaghan's study of Spicer's translations of Lorca into American English: E. Keenaghan, "Jack Spicer's Pricks and Cocksuckers: Translating Homosexuality into Visibility", in The Translator 4: 2, 1998, pp. 273-294. 
specificity. The challenge for translation scholars is not just to describe such transformations, but also to explain them. In what follows, this is done with recourse to the culturally-specific ways in which gay identity and community are conceived of and signalled.

When Tony Kushner's play Angels in America, A Gay Fantasia on National Themes; Part One: Millennium Approaches (1992) was first produced in America and Britain in the early 1990s, it was hailed by critics as a major event in English-language theatre ${ }^{26}$. The themes it explored - AIDS, death, faith, American socio-cultural change and crisis - were deemed vividly to encapsulate the late twentieth-century Zeitgeist. The play seemed immediately to accede to that rarefied cultural realm in which works of literature enjoy the status of universal validity. Thus, after noting sourly that "politicised homosexual writers have a tendency to proselytize", theatre critic Irving Wardle conceded that Kushner had produced "a vision of America at large, pulsating with energy and appetites in the shadow of history and the sense of oncoming disaster"27. However, the play was also - perhaps, above all - about a group of gay men at a crucial time in American gay politics and cultural advance. Of the main characters, Prior, Louis and Belize - three gay men - stand out ${ }^{28}$. The loves and friendships of these three men are at the emotional centre of the play. Seen in this way, Millennium Approaches is a "gay play" as much as it is a play that happens to feature homosexual characters. Note, in this connection, the (oft-forgotten) subtitle of the play, A Gay Fantasia on National Themes. Kushner's dedication also playfully yet unambiguously places the work within the context of his own experience of gay bonding:

Millennium Approaches is for Mark Bronnenberg, my favourite lover, my forever friend, my safe haven and my favourite homosexual.

${ }^{26}$ In Britain, Kushner's work won the best play category in the 1992 Evening Standard theatre awards.

${ }^{27}$ See, I. Wardle, "When Thinking Big is not Enough", in the UK newspaper, The Independent, January 26, 1992.

${ }^{28}$ Prior is currently the boyfriend of Louis, and formerly the lover of Belize; Belize is Prior's closest friend and helper during his struggle with an AIDSrelated disease. 
In the texture of play's language there is also much gay-marked material. Thus, the banter between the gay characters - particularly between Prior and Belize - draws directly on gay-specific cultural allusions and on the semiotic resource of camp. In short, what we have with Millennium Approaches is a major work of theatre that explores gay friendships from a gay perspective. Gay difference in the text is no longer suppressed or diminished; on the contrary, the gay verbal idiom is presented in a way that straight viewers/readers need sometimes to work at in order to understand.

Towards the end of the play, as Prior's health worsens, Louis and Belize have a conversation in a coffee shop during which Louis voices his own feelings of despair - about the political state of America, about his love for Prior, about his own health. Belize counters Louis's tendencies to self-indulgence with camp humour. After Belize tells Louis to "cheer up", the following exchange occurs:

BELIZE: [...] Look at that heavy sky out there...

LOUIS: Purple.

BELIZE: Purple? Boy, what kind of homosexual are you, anyway? That's not purple, Mary, that colour up there is (Very grand.) mauve.

(Tony Kushner (1992), Angels in America, A Gay Fantasia on National Themes; Part One: Millennium Approaches, IIIiii, p.76)

Here, a single adjective is a site of subcultural investment. The source of the humour is Belize's self-parody as a gay man, whose attributes are supposed to include the kind of sensitivity to colour discrimination that makes homosexuals, stereotypically, suited to careers as interior designers and hairdressers ${ }^{29}$. In the context of the play from which the example above is taken, it is significant that Louis should fail to

29 Interestingly, "mauve" is one of the words R. Lakoff, in Language and Woman's Place (New York, Harper and Row, 1975), chose to illustrate her contention that "talking like a lady" (p. 8) involved making use of a larger and more discriminating selection of colour terms than were supposed to be used by men. If a man did employ a term such as "mauve", Lakoff suggested, "one might well conclude he was imitating a woman sarcastically or was a homosexual or an interior decorator" (p. 8). 
produce the gay-marked term. He is shown throughout as both wavering in his support for Prior and also tempted by an assimilationist model of gay social acceptance. Belize's humorous comment, supposedly at his own expense as a deviant male, is in fact a barb directed at Louis's lack of political and personal commitment to "gay" as a communal value. The manner of encoding of the challenge, of course, contains a paradox. The question "What kind of homosexual are you?" both questions the addressee's status as belonging to the group while reinforcing that belonging. Thus, while the surface aim of the question is to criticise Louis's absence of subcultural semiotic awareness, the effect is (to attempt) to bring him back into the fold through the device of presupposition. After all, the question presupposes that he "is" a homosexual, even if not a very good one.

The French translation of the play renders the passage commented on above in the following way:

BELIZE: [...] Regarde comme le ciel est lourd là-haut...

LOUIS: Pourpre.

BELIZE: Pourpre? Mais, enfin, quel genre d'homosexuel es-tu? Ça ce n'est pas du pourpre, Josiane, cette couleur là-haut (Très grandiose) c'est du mauve.

(Tony Kushner (1992), Angels in America, Fantaisie gay sur des thèmes nationaux; Première Partie: Le Millénaire approche, translated by Gerrard Wacjmann with the collaboration of Jacqueline Lichtenstein (1994): IIIii, p. 65)

What interests a reader from a gay perspective here is not, of course, the potential systemic mismatch in colour terms. Thus, the question of whether "pourpre" and "mauve" are the translation equivalents of "purple" and "mauve", respectively, is largely irrelevant to the translation of this passage. In contrast, if the joke is to work in both texts (and cultures) the stereotype of gay sensitivity to colour discrimination must function similarly. What is more, the question "quel genre d'homosexuel es-tu?" needs to operate as a paradoxical reinforcer of identity and communal belonging if it is to have the same value as "what kind of homosexual are you?". I would like to suggest that while the issue of gay colour sensitivity is a comparable resource for the joke in both source and target cultures, the identity and community value of "homosexual" is different between these cultures. 
Specifically, Belize's humorous tactic for re-affirming Louis' identity is blocked. How does this come about?

I have argued elsewhere $e^{30}$ that the status of subcultural identities, while highlighted in recent Anglo-American socio-cultural thinking and political activism, is diminished in France as a consequence of the influence of a universalising notion of subjectivity that can be traced back to Enlightenment thinking. There is thus a hostility in France towards any perceived "retreat" into subcultural communitarianism $^{31}$. Similarly, White (1997) has outlined a Gallic resistance to the notion of "gay literature" even among writers whose homosexuality forms the major thematic preoccupation of their work ${ }^{32}$. We can see the effects of this socio-cultural difference in the key use of the name "Mary" as a vocative in the English text and its translation as "Josiane" in French. The names appear at a crucial moment in Belize's setting up of the humour. First, in the sentence "That's not purple, Mary, that colour up there is (Very grand.) mauve", "Mary" prosodically provides the springboard from which the emphatic appearance of "mauve" gains its comic energy. But more importantly, by employing "Mary" Belize further reinforces Louis's identity as a gay man as well as his communal attachment. For an Anglo-American socialised gay man, "Mary" is not just a randomly chosen female name (carrying out the kind of gender inversion typical in camp). Rather, it is a word that is often employed as a synonym for "homosexual". Thus, a collocation such as "Muscle Mary" is gay idiom for a gay man who goes regularly to the gym to bodybuild. In short, after asking what kind of gay man Louis is, Belize reaffirms Louis's gay identity by calling

${ }^{30}$ See K. Harvey, "Translating Camp Talk: Gay Identities and Cultural Transfer", in The Translator 4: 2, 1998, pp. 310-11.

${ }^{31}$ For example, see the comments in F. Martel, Le Rose et le Noir : les homosexuels en France depuis 1968, Paris, Les Éditions du Seuil, 1996, p. 404.

${ }^{32}$ In E. White, "AIDS Awareness and Gay Culture in France", in Acting on AIDS: Sex, Drugs and Politics, eds. J. Oppenheimer and H. Reckitt, London and New York, Serpent's Tail, pp. 339-345; see also the interview with Renaud Camus in B. Vercier, "An Interview with Renaud Camus", in Same Sex/Different Text?: Gay and Lesbian Writing in French, Yale French Studies, $\mathrm{n}^{\circ}$ 90, New Haven, Connecticut: Yale University Press, pp. 7-21. 
him a Mary. Turning to the French translation, we note that the text employs a female name, "Josiane", that does indeed have comic potential for a target reader/audience. In the target culture this name evokes several stereotypical ideas: a working class woman, loudmouthed and probably coarse, possibly from an older generation. In other words, "Josiane" would certainly raise a smile in the target text reader. However, crucially, it will not set off resonances for the target text gay reader in the way that "Mary" does for the source text gay reader. Nor will "Josiane" function with the same interpersonal force between the characters Belize and Louis in the French play as "Mary" will in the English play. In short, the circle of gay meanings that is channelled through a single word in the source text - from writer through characters, between characters, and also through to reader - is diminished in its specificity in the translation. There is still camp in the target text as a result of the gender inversion that is operated through "Josiane"; but it is a camp that is established by straight, dominantcultural means.

It is important to stress here that I am not suggesting that the target text is defective and fails to reproduce the rich meanings of the original. Rather, I would argue that in this small instance of translation we find a trace of much larger socio-cultural attitudes with regard to issues of subcultural identity/community, attitudes which form part of the complex context within which the translator acts. One could argue that the differing status of the notion of community predicated on a gay subcultural identity in the target culture results in the translator making decisions that produce a type of target-cultural gain as well as sourcecultural loss. Thus, the French Belize in the passage under consideration draws on a target cultural resource of humour that has the effect of producing him as less homosexually different than his American counterpart. Militant English-language gay readers might find this transformation problematic; French gay readers might easily accommodate it within their own conception of the (diminished) role that sexuality can play in the process of identity formation.

\section{Conclusion}

In this article I have sought to explore some of the issues raised by the complexities of identity and community in contemporary gay thought 
and life - and, specifically, to relate those issues to the problematics of the translated text. In particular, I have suggested that translated literature occupies a special place within the space of literature for gay readers in that translated texts can suggest models of otherness that can be used in processes of internal identity formation and imagined community projection. Translations can achieve this through their subject matter itself, if this presents the reader with explicit accounts of homosexual experience and struggle. But perhaps just as important is the way in which the presence of translatedness in a target culture provides readers who are working at a skew with dominant culture norms the space in which their difference can be worked out as a positive cultural attribute. As a development of this idea, I have described how the reading of a text explicitly concerned with the difficulties and disjunctures of sexual identification can actually be heightened in and through translation. Finally, in an attempt to avoid a retreat into the type of translation criticism which strives point by point to devalue the target text in relation to its source, I have argued that the diminished surface textual features of gay identity formation and reinforcement in a target text are the consequence of cultural pressures and not the translators' deficiencies. This example shows the extent to which translated texts - down to their micro-features - cannot start to be explained without recourse to larger cultural debates and to the concepts central to the (sub)cultures from which they have issued and into which they re-emerge. The methodological challenges that a statement such as this entails currently represent some of the most pressing issues in translation studies. Approaching these issues through the exploration of gayness as a literary and cultural phenomenon can, I contend, contribute significantly to their successful elaboration.

University of East Anglia

\section{References}

Primary texts

FORSTER, E.M. (1971). Maurice. London, Edward Arnold.

GIDE, André (1978). Journals 1889-1949. Translated, selected and edited by Justin O'Brien. Harmondsworth, Penguin. 
- (1984) Corydon. Translated and with a preface by Richard Howard. New York, Farrar, Straus and Giroux.

GOYTISOLO, Juan (1986). En Los Reinos de Taifa. English translation by Peter Bush (1990). In Realms of Strife. London, Quartet Books.

HOLLERAN, Andrew (1978). The Dancer From the Dance. New York, Morrow.

KRAMER, Larry (1978). Faggots. New York, Random House.

- (1985) The Normal Heart. London, Methuen.

KUSHNER, Tony (1992). Angels In America, A Gay Fantasia on National Themes; Part One: Millennium Approaches. London, Royal National Theatre and Nick Hern Books. French translation by Gérard Wacjmann with the collaboration of Jacqueline Lichtenstein (1994). Angels in America, Fantaisie gay sur des thèmes nationaux; Première Partie : Le Millénaire approche. Paris, L’Avant-Scène.

LOUYS, Pierre (1990). Les Chansons de Bilitis. Éd. J-P. Goujon. Paris, Gallimard.

PROUST, Marcel (1991, this edition in 3 volumes). In Remembrance of Things Past. Translated by C.K. Scott-Moncrief and Terence Kilmartin. (original title $\dot{A}$ la recherche du temps perdu. Paris, Nouvelle Revue Française, 1925).

WHITE, Edmund (1982). A Boy's Own Story. London, Picador.

- (1988). The Beautiful Room Is Empty. London, Picador.

- (1997). The Farewell Symphony. London, Chatto and Windus.

Secondary texts

ANDERSON, Benedict (1983). Imagined Communities: Reflections on the Origins and Spread of Nationalism. London, Verso. 
BASSNETT, Susan $\left(1991,2^{\text {nd }}\right.$ ed.). Translation Studies. London, Routledge.

BAWER, Bruce (1993). A Place at the Table: The Gay Individual in American Society. New York and London, Poseidon Press.

- (1996). (ed.) Beyond Queer: Challenging Queer Left Orthodoxy. New York, The Free Press.

BERMAN, Antoine (1984). L'Épreuve de l'étranger : culture et traduction dans l'Allemagne romantique. Paris, Gallimard.

BUTLER, Judith (1990). Gender Trouble: Feminism and the Subversion of Identity. New York and London, Routledge.

DONOVAN, James, M. (1992). "Homosexual, Gay, and Lesbian: Defining the Words and Sampling the Populations". Gay and Lesbian Studies. Ed. H. L. Minton. New York, Harrington Park Press, pp. 2747.

EVEN-ZOHAR, Itamar (1979). "Polysystem Theory". Poetics Today, Vol. $1, \mathrm{n}^{\mathrm{os}} 1-2$, pp. $287-310$.

HALL, R.W. (1988). "Gay Fiction Comes Home". New York Times Book Review, 19 June, 1988.

HALPERIN, David (1995). Saint Foucault: Towards a Gay Hagiography. New York and Oxford, Oxford University Press.

HARVEY, Keith (1998). "Translating Camp Talk: Gay Identities and Cultural Transfer". The Translator 4: 2 (on "Translation and Minority", guest edited by Lawrence Venuti), pp. 295-320.

HUMPHRIES, Martin (1985). "Gay Machismo". The Sexuality of Men. Ed. A. Metcalf, and M. Humphries. London, Pluto Press.

KEENAGHAN, Eric (1998). "Jack Spicer's Pricks and Cocksuckers: Translating Homosexuality into Visibility". The Translator 4: 2 (on 
"Translation and Minority", guest edited by Lawrence Venuti), pp. 273-294.

LAKOFF, Robin (1975). Language and Woman's Place. New York, Harper and Row.

LEAVITT, David (1995). "Introduction". The Penguin Book of International Gay Writing. Ed. M. Mitchell. Harmondsworth, Penguin, pp. xiii-xx.

LUCAS, Ian (1994). Impertinent Decorum: Gay Theatrical Manceuvres. London, Cassell.

MARTEL, Frédéric (1996). Le Rose et le Noir : les homosexuels en France depuis 1968. Paris, Les Éditions du Seuil.

MEDHURST, Andy (1991). "That Special Thrill: Brief Encounter, Homosexuality and Authorship". Screen 32/2. Summer 1991, pp. 197208.

MURRAY, Stephen O. (1995). "Stigma Transformation and Reflexification in the International Diffusion of Gay". Beyond the Lavender Lexicon: Authenticity, Imagination, and Appropriation in Lesbian and Gay Languages. Ed. W. Leap. Luxembourg, Gordon and Breach, pp. 297-315.

ROBINSON, Christopher (1995). Scandal in the Ink: Male and Female Homosexuality in Twentieth-century French Literature. London, Cassell.

SCOTT, Peter (1998). "Britain's San Francisco", $F^{* * *}$ sheet: The Journal of Gay Men Fighting AIDS. No 42, July 1998, p. 1.

SEDGWICK, Eve Kosofsky (1991). Epistemology of the Closet. London, Harvester Wheatsheaf.

SINFIELD, Alan (1994a). The Wilde Century: Effeminacy, Oscar Wilde and the Queer Moment. London, Cassell. 
- (1994b). Cultural Politics - Queer Reading. London, Routledge and Philadelphia/ University of Pennsylvania.

— (1998). Gay and After. London, Serpent's Tail.

SPIVAK, Gayatri (1987). In Other Worlds: Essays in Cultural Politics. New York, Methuen.

STANTON, Domna C. (1993). "Introduction: The Subject of Sexuality" Discourses of Sexuality from Aristotle to AIDS. Ed. D. C. Stanton, Ann Arbor. University of Michigan, pp. 1-46.

SULLIVAN, Andrew (1995). Virtually Normal: An Argument About Homosexuality. London, Picador.

- (1996). "The Politics of Homosexuality". Beyond Queer: Challenging Queer Left Orthodoxy. Ed. B. Bawer. New York, The Free Press, pp. 60-85.

TOURY, Gideon (1995). Descriptive Translation Studies and Beyond. Amsterdam, John Benjamins.

VENUTI, Lawrence (1998). The Scandals of Translation: Towards an Ethics of Difference. London and New York, Routledge.

VERCIER, Bruno (1996). "An Interview with Renaud Camus". Same Sex/Different Text?: Gay and Lesbian Writing in French. Yale French Studies, Number 90. Eds. B. Mahuzier, K. McPherson, C. A. Porter and R. Saronak. New Haven, Connecticut, Yale University Press, pp. 7-21.

WARDLE, Irving (1992). "When Thinking Big is not Enough". The Independent, January 26, 1992.

WARREN, Carol A. B. (1974). Identity and Community in the Gay World. New York, John Wiley.

WHITE, Edmund (1994). "Out of the Closet, on to the Bookshelf'. The Burning Library: Writings on Art, Politics and Sexuality. London, Chatto and Windus, pp. 275-283. 
- (1995). "Today the Artist is a Saint who Writes his Own Life" Edmund White on the Genre of Gay Autofiction". London Review of Books. Vol. 17, Issue 5, 9 March 1995, pp. 6-8.

- (1997). "AIDS Awareness and Gay Culture in France". Acting on AIDS: Sex, Drugs and Politics. Eds. J. Oppenheimer and H. Reckitt. London and New York, Serpent's Tail, pp. 339-345.

ABSTRACT : Gay Community, Gay Identity and the Translated Text - In this paper, the author explores the multiple intersections of the notion "gay community" and "gay identity" with the problematic of translation. First, the notions of "community" and "identity" themselves are explored for their theoretical, political and personal ramifications for the gay subject. It is argued that the two notions engage in a constant process of redefinition in relation to each other and, in particular, that they can be seen to overlap if their respective concrete/imagined and internal/external dimensions are taken account of. The author goes on to suggest how translated literature represents a crucial site for the gay person's elaboration of a distinct subjectivity. Then, an example (Spanish-English) is given of a text whose exploration of emerging gay selfhoof is enhanced in translation. Finally, a passage (English-French) is studied in its source and target versions in order to identify the pressures that different cultural conceptions of sexual identity bring to bear upon textual products.

RÉSUMÉ : Communauté gay et identité gay à l'intérieur de la traduction - Dans cet article, l'auteur explore les multiples notions de "communauté » et "d'identité" "gays et les problèmes de traduction qui en découlent. Il examine d'abord les ramifications théoriques, politiques et personnelles que peuvent avoir ces deux notions pour le sujet gay. Il soutient que ces deux notions se redéfinissent mutuellement de façon constante, et plus précisément, qu'elles semblent se chevaucher lorsque leurs dimensions concrètes/imaginées et internes/externes entrent respectivement en jeu. L'auteur affirme que les oeuvres traduites jouent un rôle crucial dans la recherche de la subjectivité distincte des gays. Par la suite, il donne un extrait d'un texte espagnol-anglais traitant de l'émergence de l'identité gay qui est mise en valeur en traduction. Enfin, un texte anglais accompagné de sa traduction française permet de voir comment des 
conceptions culturelles distinctes de l'identité sexuelle se manifestent à travers l'écrit.

Key Words: community, identity, gay, translation, literature.

Mots-clés : communauté, identité, gay, traduction, littérature.

Keith Harvey: School of Language, Linguistics and Translation Studies, University of East Anglia, Norwich NR4 7TJ, UK.

E-Mail : k.harvey@uea.ac.uk 